\title{
Cash concerns for Canadian scientists
}

\section{Could programme cuts prompt a brain drain?}

Billions of dollars in science infrastructure investments have been overshadowed by cuts to major grant-funding programmes in Canada's federal budget.

In the Can\$40-billion (US\$32.3-billion) stimulus budget released on 27 January, Prime Minister Stephen Harper's government promised Can $\$ 2$ billion to post-secondary institutions to repair and expand their facilities (see 'Canada's budget breakdown'). An estimated $70 \%$ of the cash will go to universities, much of it targeted towards upgrading existing labs.

University heads were delighted with the funding boost for bricks-and-mortar projects. "Infrastructure funding is something we lobbied for and is needed. It's very exciting," says Rose Goldstein, vice-president of research at the University of Calgary, Alberta.

The Canada Foundation for Innovation (CFI), which invests in research infrastructure, won an additional Can $\$ 750$ million. This allows the organization to add Can $\$ 150$ million to its current Can\$400-million funding round, and to launch at least one additional round before the end of 2010. "Millions more dollars of really good projects are going to be funded and that's great news," says John Hepburn, vice-president of research at the University of British Columbia in Vancouver.

The budget granted Can $\$ 110$ million to the Canadian Space Agency for research into space robotics over the next three years. But some of that money will be redirected from Can\$9.9 million in savings the agency is supposed to generate by increasing its efficiency and effectiveness through increased collaborations with academia and industry.

Arctic research infrastructure also fared well with a Can\$87-million windfall. University of Alberta ecologist David Hik says the investment is large enough to improve the ageing research stations that dot the Canadian north, but he is concerned that it is not matched by programme funding. Most Arctic research is currently supported by programmes - such as those of the International Polar Year and the Canadian Foundation for Climate and Atmospheric Sciences - that are nearing the end of their funding periods.

"The budget is good on infrastructure, but where's the money to support the graduate students, the postdocs and all the other undertakings of research that will use funding from the CFI or some other source?" says Gordon McBean, a climatologist at the University of

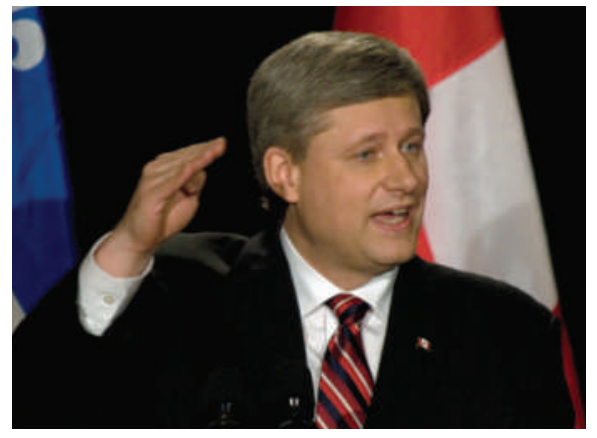

Budget builder: Prime Minister Stephen Harper.

Western Ontario in London, Ontario.

Although the budget does contain Can $\$ 87.5$ million for graduate-student scholarships, the research community is perplexed by the government's decision to cut funding to Canada's three federal granting councils. Over three years, the budgets of the Canadian Institutes of Health Research, the Natural Sciences and Engineering Research Council and the Social Sciences and Humanities Research Council will be reduced by almost Can $\$ 148$ million. "It's an unfortunate consequence of getting poor advice or not listening to good advice," says Aled Edwards, a structural biologist at the University of Toronto, Ontario, and director and chief executive of the international Structural Genomics Consortium. He argues that the most efficient way to invest in research is through the funding councils, where peer review determines where the dollars are spent.

The budget made no mention of funding for Genome Canada, a not-for-profit organization that supports large-scale, multidisciplinary international science projects and regional genome centres, including the British Columbia Cancer Agency's Genome Sciences Centre in Vancouver, which completed the first publicly available draft sequence of the SARS coronavirus in 2003. The agency received fiveyear funding packages of Can $\$ 140$ million in 2008 and Can\$100 million in 2007.

"I don't think anyone understands this decision," says Hepburn. "If they forgot Can $\$ 140$ million, it's really weird, and if it wasn't their intention then why isn't Martin Godbout [president and chief executive of Genome Canada] hearing any reassuring noises?" In a statement, Genome Canada noted that the lack of funding will not affect any of its current projects.

But the long-term effect of cutting funds for research may be that Canadian scientists will take their research south of the border, says Edwards. Canada's research funding pales in comparison with that in the United States, and the latest budget threatens to widen the gap between the two countries, he adds. "We're at serious risk of a brain drain."

Hannah Hoag

\begin{tabular}{|c|c|c|}
\hline How much? & Who gets the cash? & What is the funding for? \\
\hline$\$ 2$ billion & Post-secondary institutions & To repair and expand facilities \\
\hline$\$ 1$ billion & Green Infrastructure Fund & To support projects such as sustainable energy up to 2014 \\
\hline$\$ 750$ million & Canada Foundation for Innovation & $\begin{array}{l}\$ 150 \text { million for current funding round; } \$ 600 \text { million to } \\
\text { launch one or more new funding rounds by } 2010\end{array}$ \\
\hline$\$ 250$ million & $\begin{array}{l}\text { Public Works and Government } \\
\text { Services Canada }\end{array}$ & $\begin{array}{l}\text { To modernize key federal laboratories over the } \\
\text { next two years }\end{array}$ \\
\hline$\$ 351$ million & Atomic Energy of Canada & $\begin{array}{l}\text { To support operations including nuclear-power research } \\
\text { at Chalk River Laboratories, Ontario }\end{array}$ \\
\hline$\$ 110$ million & Canadian Space Agency & $\begin{array}{l}\text { Development of prototypes for space robotics vehicles } \\
\text { over the next three years }\end{array}$ \\
\hline$\$ 87$ million & $\begin{array}{l}\text { Indian and Northern } \\
\text { Affairs Canada }\end{array}$ & $\begin{array}{l}\$ 2 \text { million for High Arctic research station feasibility } \\
\text { study; } \$ 85 \text { million over two years to upgrade and } \\
\text { maintain existing Arctic research facilities }\end{array}$ \\
\hline$\$ 50$ million & $\begin{array}{l}\text { Institute for Quantum Computing } \\
\text { (University of Waterloo, Ontario) }\end{array}$ & $\begin{array}{l}\$ 25 \text { million to complete the Quantum-Nano Centre; } \\
\$ 25 \text { million for operations and recruitment of researchers }\end{array}$ \\
\hline$\$ 10$ million & Multi-agency & $\begin{array}{l}\text { To improve reporting on clean air, clean water and } \\
\text { greenhouse-gas emissions in 2009-10 }\end{array}$ \\
\hline
\end{tabular}

